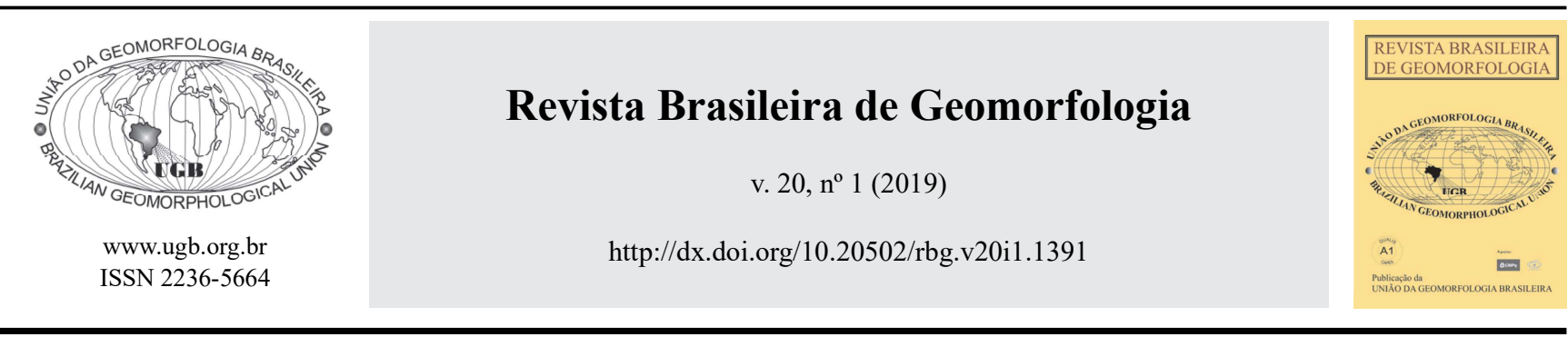

\title{
TÉCNICAS DE MAPEAMENTO GEOMORFOLÓGICO APLICADAS EM ESCALA DE DETALHE
}

\section{GEOMORPHOLOGICAL MAPPING TECHNIQUES APPLIED IN DETAIL SCALE}

\author{
Alexandre dos Santos Souza \\ Departamento de Geociências, Universidade Federal da Paraíba \\ Cidade Universitária, Castelo Branco, João Pessoa-PB, CEP 58051-900 \\ E-mail:alesougeo@gmail.com
}

Max Furrier
Departamento de Geociências, Universidade Federal da Paraíba
Cidade Universitária, Castelo Branco, João Pessoa-PB, CEP 58051-900

E-mail: max_furrier@hotmail.com

\section{Informações sobre o Artigo}

Recebido (Received):

30/07/2018

Aceito (Accepted):

08/10/2018

\section{Palavras-chave:}

Borda oriental da Paraíba; Mapeamento geomorfológico; Carta topográfica.

\section{Keywords:}

Eastern border of Paraíba; Geomorphological mapping; Topographic map.

\section{Resumo:}

As cartas topográficas com escala de detalhe constituem uma base extraordinária para mapeamentos sistemáticos e desenvolvimento de pesquisas que se dedicam aos estudos geomorfológicos e áreas afins, uma vez que os produtos cartográficos elaborados possibilitam a compreensão de diferentes características físicas do relevo. O presente trabalho, realizado a partir de uma carta topográfica na escala de 1:25.000, localizada na borda oriental do estado da Paraíba, aplica, em ambiente de Sistema de Informação Geográfica (SIG), técnicas de elaboração de mapas físicos, Modelo Digital de Elevação (MDE) e perfis topográficos, a partir de informações obtidas inicialmente da vetorização manual de todas as curvas de nível e pontos cotados identificados sobre a carta topográfica. Os resultados obtidos expuseram, com escala de detalhe proporcionado pela precisão da carta topográfica, a taxonomia dos diversos padrões de formas do relevo. Os produtos gerados possibilitaram uma visão inédita das formas resultantes da interface entre Geologia e Geomorfologia na configuração do relevo, e corroboram a importância da metodologia empregada para cartografia geomorfológica como subsídio para o estudo do relevo, uma vez que permitiram mapear e caracterizar, com precisão, as discrepâncias altimétricas, a morfologia dos terrenos sedimentares e cristalinos, a rede de drenagem, além das formas que os processos erosivos e deposicionais atuais produzem, como voçorocas, ravinas e planícies fluviais.

\section{Abstract:}

Topographic charts in detail scale constitute an extraordinary basis for systematic mapping and development of researches that draw on geomorphological studies and related areas, since the cartographic products that are designed allow the 
understanding of different physical characteristics of the relief. The present study is based on a topographic map on the 1:25.000 scale of the Paraíba State's eastern border and it employs, by usinga Geographic Information System (GIS), environment techniques for the elaboration of physical maps, Digital Elevation Model (DEM) and topographic profiles based on information obtained initially from the manual vectorization of all contour lines and elevation points identified on the topographic map. The results obtained showed in detail scale provided by the topographical chart's accuracy the taxonomy of different landscape patterns. The products generated allowed a groundbreaking view of the resulting forms of the interface between Geology and Geomorphology in the relief configuration, and corroborate the importance of the methodology used for geomorphological cartography as a subsidy for the relief study, since they allowed to accurately map and characterize the altimetric discrepancies, the morphology of the sedimentary and crystalline terrains, the drainage network, and the forms that the present erosive and depositional processes produce, such as gullies, ravines and fluvial plains.

\section{Introdução}

O uso de cartas topográficas em estudos geomorfológicos é de grande relevância, não só em estudos que envolvam a própria geomorfologia, mas também na elaboração de trabalhos direcionados ao planejamento de obras de engenharia, questões ambientais, desenvolvimento agrícola, exploração mineral, entre outros. Nessa perspectiva, de acordo com Maia e Bezerra (2012), estudar o relevo a partir de bases cartográficas e metodologias específicas extraídas da Geomorfologia, da Geologia, da Matemática e do Geoprocessamento, tem se tornado um meio eficaz de averiguação e análise do padrão morfológico resultante da interface entre os agentes endógenos e exógenos.

De acordo com Dikau (1989) e Silveira et al. (2014), as técnicas aplicadas em mapeamentos digitais viabilizam o cruzamento de informações e resultados obtidos a partir de bases de dados variadas, sobre os quais é possível identificar com detalhe as feições do relevo.

Nessa perspectiva, observa-se que um dos meios mais eficazes aplicados nos estudos geomorfológicos é o mapeamento do relevo em escala de detalhe que estabeleça visão clara sobre a taxonomia e mecanismos que deram origem às feições geomórficas. Dessa forma, os mapeamentos temáticos se tornam essenciais em Geomorfologia, principalmente para o planejamento do uso e ocupação do solo (MARQUES, 2007; RODRIGUES; OLIVEIRA, 2007; ROSS, 1992).

A metodologia do mapeamento geomorfológico aplicado neste trabalho permitiu a elaboração de produtos cartográficos com escala de detalhe e a ordenação das morfologias mapeadas em conformidade com uma taxonomia apropriada. Para Souza (2015), "devido ao déficit de mapeamentos planialtimétricos, em grandes e médias escalas, no Brasil [...], há uma dificuldade na obtenção e processamento de informações topográficas nessas escalas". Todavia, com o emprego das novas tecnologias e a disponibilidade de Sistemas de Informação Geográfica (SIGs) gratuitos, a elaboração desses mapas tem se tornado cada vez mais usual.

A área de estudo é parte integrante da borda continental leste da América do Sul. Essa porção do território brasileiro, apresentada como "passiva", possui extensas bacias cortadas por riftes desenvolvidos durante a separação da América do Sul do continente africano no Jurássico-Cretáceo (BEZERRA; MELLO; SUGUIO, 2006). No caso do Brasil, observa-se que a projeção dessas bacias se formou seguindo os estágios tectônicos descritos por Asmus (1975) (Figura 1). Tal dinâmica evolutiva, associada aos fatores exógenos atuantes, é responsável pela configuração do relevo analisado no presente trabalho.

A carta selecionada para o trabalho integra o Catálogo das Cartas Topográficas do Nordeste do Brasil. O catálogo, também denominado de Saliente Oriental Nordestino, contempla cartas topográficas, na escala de 1:25.000, de partes da Paraíba, Pernambuco e Alagoas, cujo levantamento cartográfico da área se destina a elaborações de projetos, estudos e pesquisas imprescindíveis ao desenvolvimento econômico regional e setorial (BRASIL, 2013). Os limites da carta analisada neste trabalho estão definidos pelos paralelos $6^{\circ} 45^{\prime} 00^{\prime \prime}$ ao norte e $6^{\circ} 52^{\prime} 30^{\prime \prime}$ ao sul; e meridianos $35^{\circ} 15^{\prime} 00^{\prime \prime}$ ao oeste e $35^{\circ} 7^{\prime} 30^{\prime \prime}$ ao leste, contemplando porções dos municípios de Curral de Cima, Capim, Cuité de Mamanguape, Rio Tinto, Mamanguape e Itapororoca, localizados na microrregião do Litoral Norte Paraibano (Figura 2). 
Técnicas de Mapeamento Geomorfológico Aplicadas em Escala de Detalhe

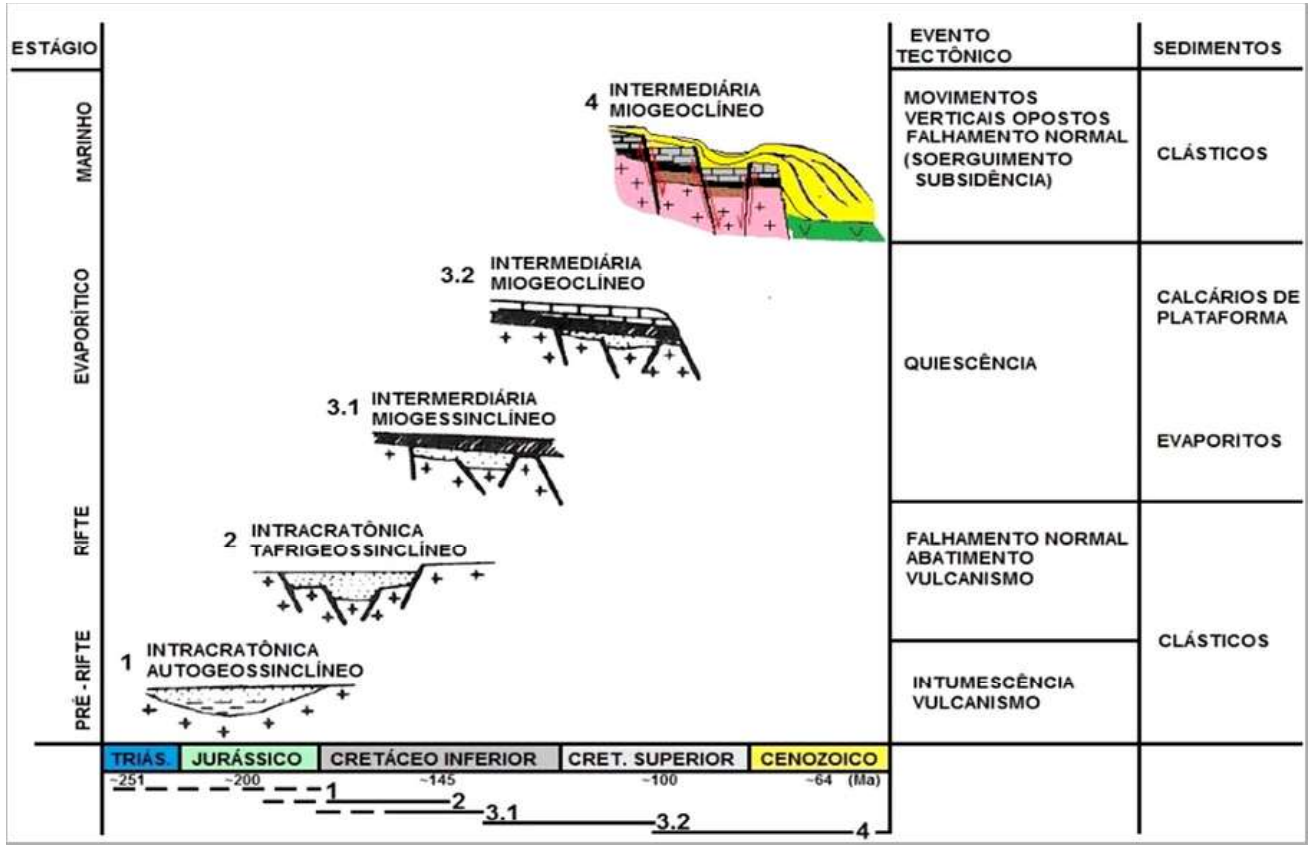

Figura 1 -Evolução dos estágios tectônicos ocorridos nas bacias sedimentares do Brasil. Observar alterações ocorridas no estágio 4 onde mostra os calcários extremamente falhados embaixo da Formação Barreiras. Fonte: adaptado de Asmus (1975).

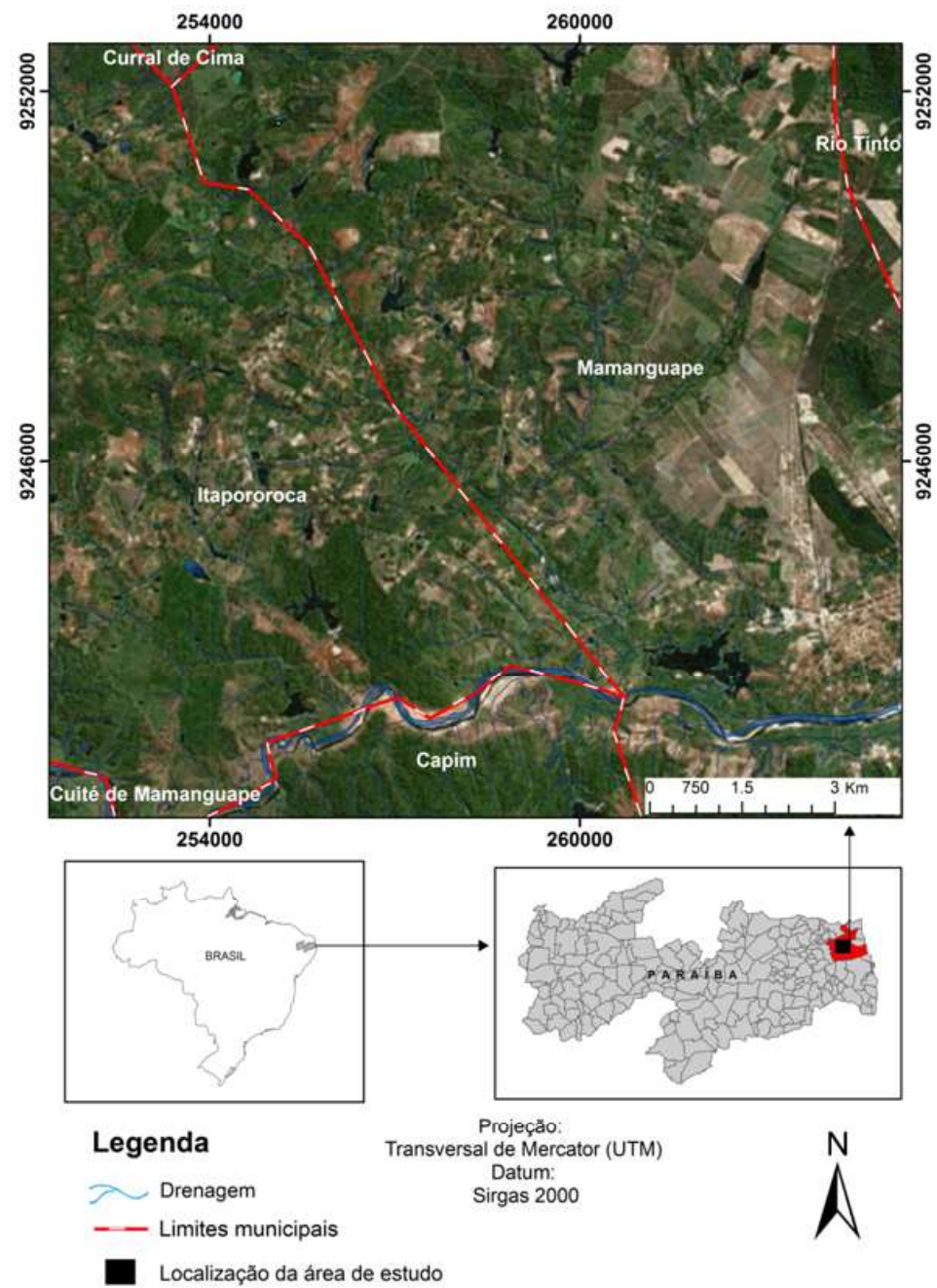

Figura 2 - Localização da área de estudo. Fonte: elaboração própria. 
Os resultados obtidos nesta pesquisa apresentam informações detalhadas do relevo com a precisão da carta topográfica utilizada. Esses resultados produzem uma base de dados bastante confiável, haja vista que a carta topográfica base foi produzida por aerolevantamento planialtimétrico com apoio em solo, portanto, com um detalhamento extremamente elevado. Dessa forma, foi possível elaborar mapas temáticos e modelos escalares particularizados das unidades geomorfológicas que permitiram uma avaliação detalhada do terreno, uma vez que os produtos gerados viabilizam a representação dos elementos geomorfológicos e ampliam o entendimento das peculiaridades do relevo.

\section{Materiais e Método}

Neste trabalho, em face da disponibilidade da base cartográfica almejada em grande escala, utilizou-se como objeto de análise a folha Itapororoca (SB.25-YA-V-4-NO), localizada na borda oriental do estado da Paraíba, desenvolvida pelo Serviço de Cartografia da Divisão de Recursos Naturais da Superintendência do Desenvolvimento do Nordeste (SUDENE), na escala de 1:25.000, com equidistância entre as curvas de nível de 10m (BRASIL, 1974).

Para o ajuste do mapa geológico à escala de 1:25.000, executaram-se trabalhos de campo com o apoio de Global Positioning System (GPS), fotografias aéreas e imagens orbitais, visando a correta adequação das litologias apresentadas no mapa geológico original do estado da Paraíba em escala de 1:500.000 (SANTOS; FERREIRA; SILVA JÚNIOR, 2002) com as curvas de nível da carta topográfica base e com as formas do relevo visualizadas nas fotografias aéreas e nas imagens orbitais. Salienta-se que essa metodologia para o ajuste do mapa geológico à escala da carta topográfica somente foi possível devido ao reduzido número de litologias encontradas na área. Definidas as áreas ajustadas de abrangência das litologias encontradas, iniciou-se a vetorização delas delimitando os domínios geológicos em meio digital.

A cartografia geomorfológica é importante para o estudo do relevo, pois a confecção do mapa geomorfológico fornece um produto capaz de sintetizar, por intermédio de procedimentos técnico-metodológicos, os resultados das respectivas investigações (ROSS, 1992). Para a confecção do mapa geomorfológico, utilizou-se, como critério de interpretação das unidades morfológicas e parâmetro basilar, o modelo de Ross (1992), que estabeleceu as unidades taxonômicas de classificação do relevo, aplicado em cartas de 1:10.000 e 1:25.000 a partir de imagens aerofotogramétricas, consideradas de grande escala. Para elaborar sua proposta de representação taxonômica (Figura 3), Ross (1992) partiu das premissas apresentadas por Penck (1953), que definiu as formas do relevo como produto da interação dos processos endógenos e exógenos, possíveis de se mapear em grande escala em seis níveis taxonômicos.

Para demonstração dos padrões de forma de relevo, a partir da metodologia utilizada, aplica-se um conjunto de algarismos arábicos em consonância a uma matriz previamente elaborada, cujas colunas indicam os valores de entalhamento dos vales e as linhas a dimensão interfluvial média (Tabela 1). As formas agradacionais não recebem os algarismos arábicos, pois não representam dissecação por processos erosivos. De maneira geral, esses padrões caracterizam-se por diferentes intensidades de dissecação do relevo por influência dos cursos de água (ROSS, 1992).

O índice de dissecação do relevo deve levar em consideração o entalhamento médio dos vales e a dimensão interfluvial média. Para se calcular os entalhamentos fluviais, é imprescindível levar-se em consideração a estrutura geológica/geomorfológica regional e a hierarquização da rede de drenagem. Para a hierarquização e caracterização dos padrões de formas de relevo é necessário utilizar a carta topográfica da área, sobre a qual deve-se traçar uma linha imaginária perpendicular entre dois rios de $3^{\mathrm{a}}$ ordem que definirá a dimensão interfluvial média. A obtenção do entalhamento médio dos vales faz-se pela diferença altimétrica média do divisor topográfico com a curva de nível mais próxima ao curso d'água. A diferença média de altura entre o divisor de água desses dois rios e seus respectivos fundos de vale resultará no entalhamento médio dos vales, conforme ilustrado na Figura 4.

$\mathrm{O} 1^{\circ}$ táxon corresponde à definição de morfoestrutura. Nesse táxon, prevalecem estruturas geológicas de grande extensão, mais antigas do que as unidades morfoesculturais esculpidas no seu interior. $\mathrm{O} 2^{\circ}$ táxon representa as morfoesculturas desenvolvidas sobre a morfoestrutura relacionadas com os processos erosivos ou denudacionais do Cenozoico (ROSS, 1992). 


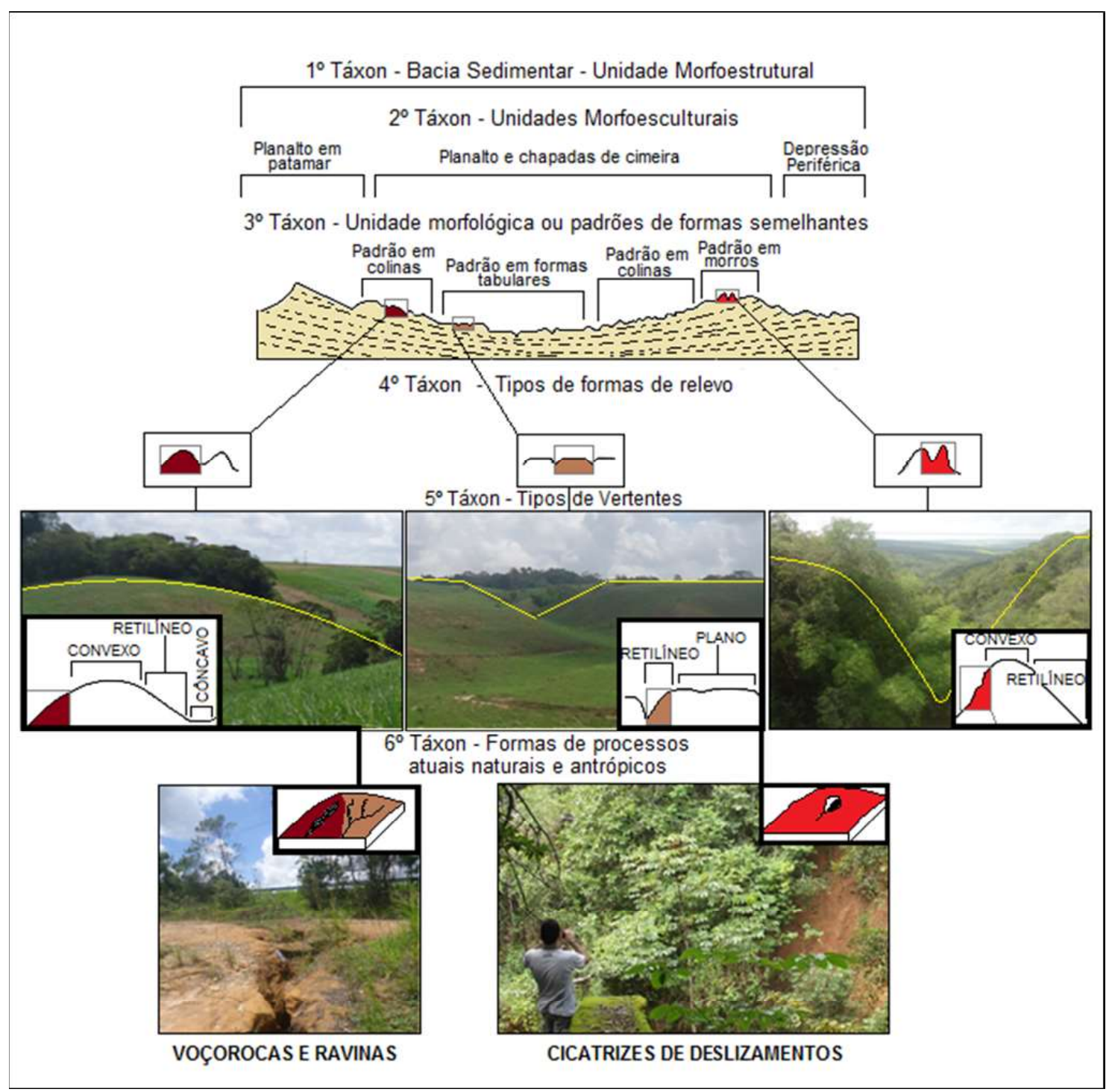

Figura 3 - Unidades taxonômicas de classificação do relevo. Fonte: Adaptado de Ross (1992), com imagens obtidas durante observações de campo na área de estudo.

Tabela 1: Matriz dos índices de dissecação do relevo

\begin{tabular}{l|c|c|c|c|c}
\hline \multirow{2}{*}{$\begin{array}{c}\text { Classes de entalhamento } \\
\text { médio dos vales }\end{array}$} & $\begin{array}{c}\text { Muito } \\
\text { grande (1) } \\
>1.500 \mathrm{~m}\end{array}$ & $\begin{array}{c}\text { Grande (2) } \\
1.500 \mathrm{a} \\
700 \mathrm{~m}\end{array}$ & $\begin{array}{c}\text { Média (3) } \\
700 \mathrm{a} \\
300 \mathrm{~m}\end{array}$ & $\begin{array}{c}\text { Pequena (4) } \\
300 \mathrm{a} \\
100 \mathrm{~m}\end{array}$ & $\begin{array}{c}\text { Muito } \\
\text { pequena (5) } \\
<10 \mathrm{~m}\end{array}$ \\
\hline Muito fraco (1) $<20 \mathrm{~m}$ & 11 & 12 & 13 & 14 & 15 \\
\hline Fraco (2) $20 \mathrm{a} 40 \mathrm{~m}$ & 21 & 22 & 23 & 24 & 25 \\
\hline Médio (3) 40 a $80 \mathrm{~m}$ & 31 & 32 & 33 & 34 & 35 \\
\hline Forte (4) $80 \mathrm{a} 160 \mathrm{~m}$ & 41 & 43 & 43 & 44 & 45 \\
\hline Muito forte (5)>160 m & 51 & 52 & 53 & 54 & 55 \\
\hline
\end{tabular}

Fonte: Ross (1992). 


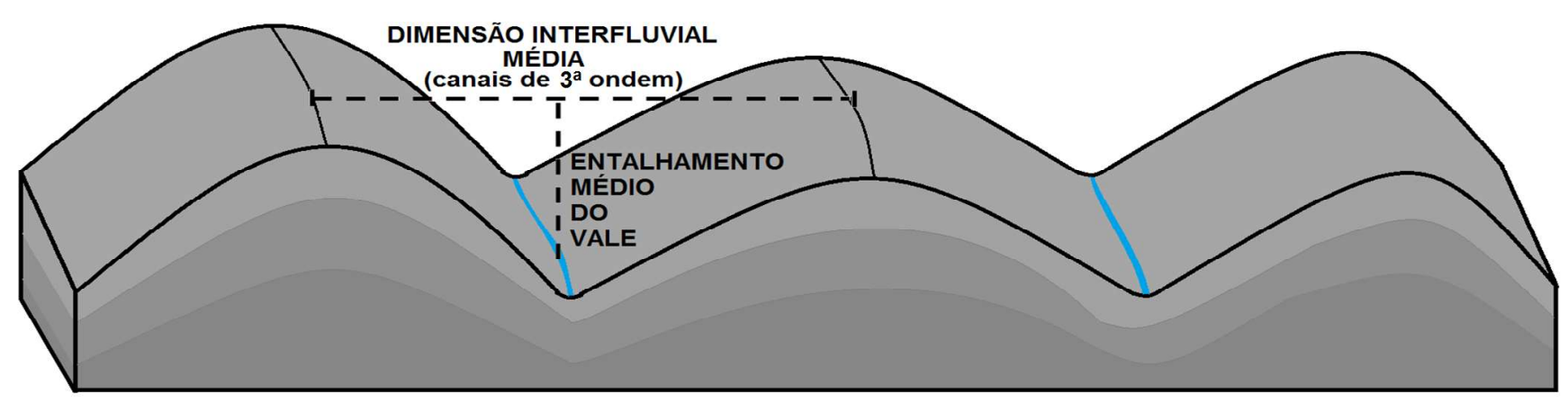

Figura 4 - Modelo esquemático para a averiguação do entalhamento médio e da dimensão interfluvial. Fonte: elaboração própria.

$\mathrm{O} 3^{\circ}$ táxon corresponde às unidades dos padrões de formas semelhantes de relevo sobre as quais podem ser identificadas diferenças como a rugosidade topográfica ou o índice de dissecação do relevo, além do comportamento da drenagem na qual os padrões e anomalias são tomados como referencial para indicar as relações entre os ambientes climáticos atuais ou passados e as condicionantes litológicas ou tectônicas (ROSS, 1992). A representação do $3^{\circ}$ táxon no mapa geomorfológico é realizada por meio de letras maiúsculas e minúsculas. Para padrões resultantes de formas denudacionais (letra D) ou de acumulação (letra A) e atrelados a estes, aplicam-se letras minúsculas para representação das formas geradas (Quadro 1).
As representações propostas por Ross (1992) foram adaptadas por Furrier (2007) para aplicação desta metodologia em relevo tabular esculpido sobre a Formação Barreiras para mapeamento na escala de 1:100.000. Esses ajustes foram feitos por meio da incorporação da denominação das formas de terraços e planícies marinhas (Atpm), formas de depósitos de colúvio, planície e terraço fluvial (Acptf) e formas de depósitos de colúvio e terraço fluvial (Actf). Outra mudança incrementada aos padrões de relevo seguindo a mesma perspectiva foi aplicada por Silva (2014), em trabalho que definiu a denominação de formas de terraços e planícies fluviais (Atpf) para as margens do rio Mamanguape, em trabalho realizado na escala de 1:25.000.

\section{Quadro 1: Padrões de formas de relevo}

\begin{tabular}{|l|l|}
\hline \multicolumn{1}{|c|}{ FORMAS DE DENUDAÇÃO } & \multicolumn{1}{c|}{ FORMAS DE ACUMULAÇÃO } \\
\hline D - Denudação & A - Acumulação \\
Da - Formas com topos aguçados & Apf - Formas de planície fluvial \\
Dc - Formas com topos convexos & Apm - Formas de planície marinha \\
& Apl - Formas de planície lacustre \\
Dt - Formas com topos tabulares & Api - Formas de planície intermarés \\
De - Formas de escarpas & Ad - Formas de campos de dunas \\
& Atf - Formas de terraço fluvial \\
\hline
\end{tabular}

Fonte: Ross (1992).

O $4^{\circ}$ táxon é caracterizado por formas específicas de relevo que se situam dentro de cada padrão de formas do relevo. No $4^{\circ}$ táxon, as formas podem ser denudacionais, como os morros, colinas e tabuleiros, e aquelas agradacionais, observadas nas planícies lacustres, fluviais e marinhas. Os tipos de forma de relevo apresentam semelhanças entre si, tanto em sua morfologia quanto em sua morfometria, isto é, em forma e dimensão. Cabe destacar que a representação cartográfica do $4^{\circ}$ táxon (tipos de forma do relevo), na metodologia aqui empregada, se faz em conjunto com a representação do $3^{\circ}$ táxon (padrões de formas do relevo).

Um ponto importante do procedimento para se caracterizar e mapear o relevo é a escolha da ordem hierárquica do curso de água. Esse procedimento metodológico foi desenvolvido pela primeira vez no 
Brasil do projeto RADAMBRASIL, por Barbosa et al. (1984) e depois ajustada por Ross (1992).

O $5^{\circ}$ táxon refere-se aos tipos de vertentes ou setores das vertentes contidas em cada uma das formas denudacionais, ou seja, convexas, côncavas, retilíneas, planas etc. São dimensões menores individualizadas do relevo, em que é geneticamente distinguida cada tipologia e geometria de forma de uma vertente. De acordo com Ross (1992), as representações desse táxon são indicadas para escalas maiores, a partir de 1:25.000. Neste trabalho, a possibilidade de caracterização do $5^{\circ}$ táxon foi exemplificada por meio de perfis topográficos elaborados em sentido Leste/Oeste.

A elaboração dos perfis topográficos utilizou software específico sobre a imagem sombreada com as curvas de nível e as cotas altimétricas. Para tanto, selecionaram-se dois trechos em sentido latitudinal para demonstração. Após traçados os perfis, realizou-se a edição das imagens geradas definindo-se o seu exagero vertical e demais toponímias necessárias.

$\mathrm{O} 6^{\circ}$ táxon representa as menores formas mapeáveis. São formas produzidas pelos processos erosivos ou deposicionais atuais. Desse táxon, pode-se citar formas causadas por agentes naturais, entre elas: voçorocas, ravinas, bancos de sedimentação atuais e formas antrópicas, como: cortes, aterros, mineração, entre outras. $\mathrm{O}$ mapeamento do $6^{\circ}$ táxon pode ser feito mediante fotografias aéreas, imagens orbitais de alta resolução e trabalhos de campo. Sua representação cartográfica, quando possível, faz-se por símbolos padronizados para feições geomorfológicas (NUNES et al., 1994), como, por exemplo: ravinas, voçorocas, cava de mineração, aterro sanitário etc.

Esses táxons, de acordo com sua ordem de grandeza, são apresentados no mapa por meio de cores, tonalidades de cores, polígonos, letras-valores e símbolos. Dessa forma, o mapa final consegue demonstrar os vários níveis de grandeza do relevo. É importante ressaltar que, para uma representação cartográfica do relevo que demonstre uma gama variada de detalhes das formas existentes, deve-se optar por escalas grandes, por meio de imagens de satélite, fotografias aéreas ou no campo, visando, assim, cartografar os fatos geomórficos a partir dos critérios e representações definidas na literatura específica.

Para a confecção do Modelo Digital de Elevação (MDE), observou-se a técnica de representação geométrica bidimensional para formas tridimensionais. Nesse procedimento, foi necessário utilizar as cotas altimétricas para que a triangulação ocorresse com maior precisão. De acordo com Chaves (2002), a partir do MDE, podese obter informações qualitativas do terreno, mediante visualizações planares, e informações quantitativas da superfície, como o cálculo da declividade e da orientação de vertentes.

\section{Resultados e Discussões}

\subsection{Mapa Geológico}

De acordo com o mapa geológico ajustado da área, as unidades geológicas estão distribuídas cronologicamente entre as eras Paleoproterozoica e Cenozoica (Figura 5). A situação geológica da região também foi detalhada em trabalhos de Brito Neves et al. (2004, 2008) e Santos, Ferreira e Silva Júnior (2002), que foram desenvolvidos em escalas menores, de 1:100.000 e 1:500.000, respectivamente. Em conformidade com esses autores, observou-se que na região ocorrem inúmeros realces de reativações tardias influenciadas pelo Lineamento Patos e, ainda, as falhas normais que alinham o baixo curso do rio Mamanguape, formando um gráben apresentado com escala de detalhe por Furrier et al. (2014).

A região também apresenta algumas litologias típicas da megaestrutura da Zona Transversal, mais precisamente no Terreno Alto Pajeú (TAP), cuja estrutura é composta por unidades gnáissicas paleoproterozoicas, metavulcanossedimentares, metaplutônicas e granitoides, que estão arranjadas entre zonas de cisalhamento transcorrentes associadas ao evento Brasiliano (SANTOS; NUTMAN; BRITO NEVES, 2004). Esses autores destacam que no baixo curso do rio Mamanguape, nas proximidades da BR-101, é possível observar exposição de rochas do embasamento, fato registrado in loco (Figura 6).

\subsection{Carta Geomorfológica}

A partir da elaboração e análise da carta geomorfológica (Figura 7), individualizaram-se as seguintes morfoestruturas para a área de estudo: para a morfoestrutura Sedimentos Quaternários, a morfoescultura corresponde é a Planície Fluvial do Rio Mamanguape; para a morfoestrutura Formação Barreiras, a morfoescultura correspondente é os Tabuleiros Litorâneos; para a morfoestrutura Rocha Vulcânica Félsica Itapororoca, a morfoescultura correspondente é o Alto Félsico Itapororoca; para o Terreno Alto Pajeú, a morfoescultura correspondente é a Depressão Sublitorânea. 
Souza A. S. \& Furrier M.
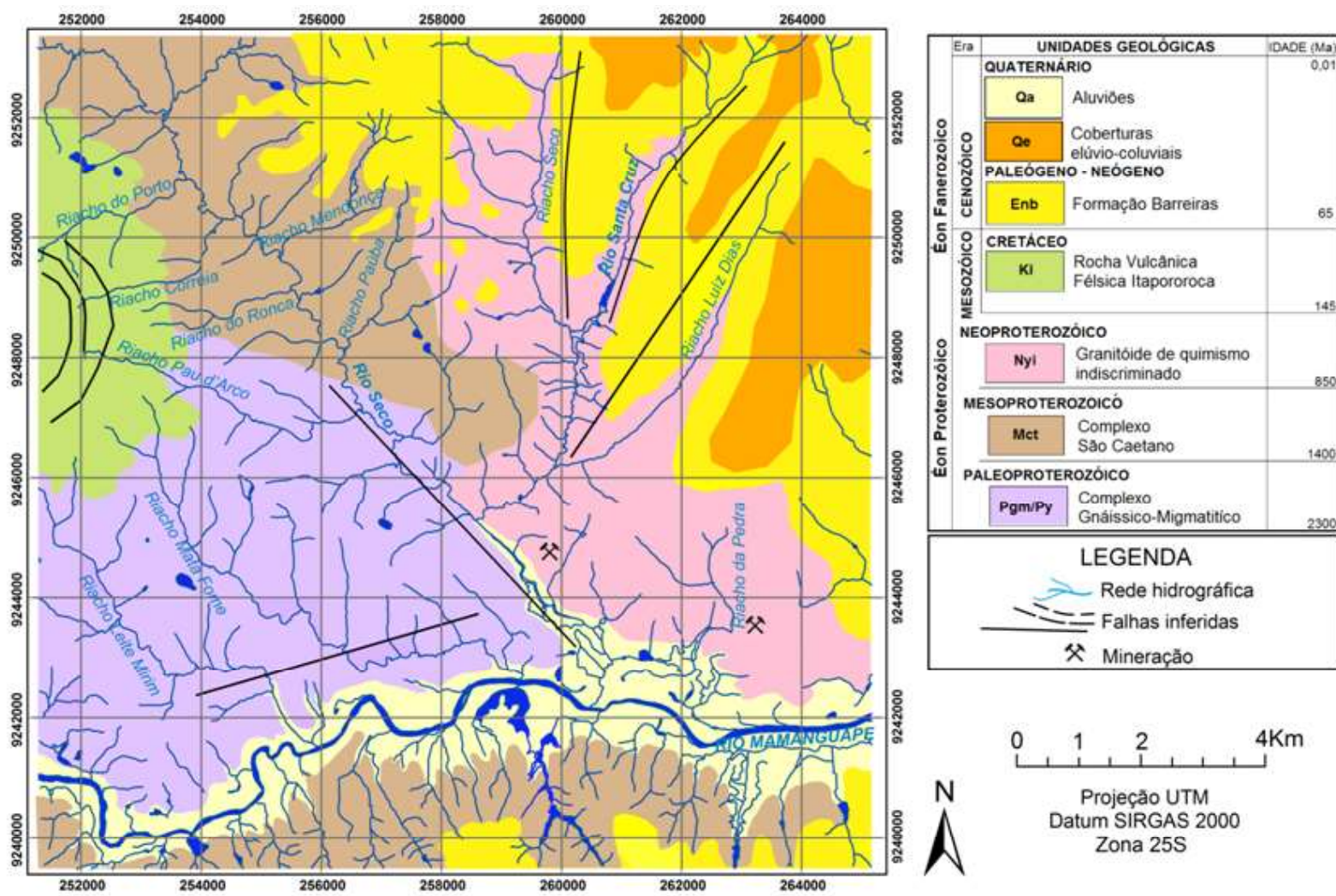

Figura 5 - Unidades geológicas da área de estudo. Fonte: elaboração própria.

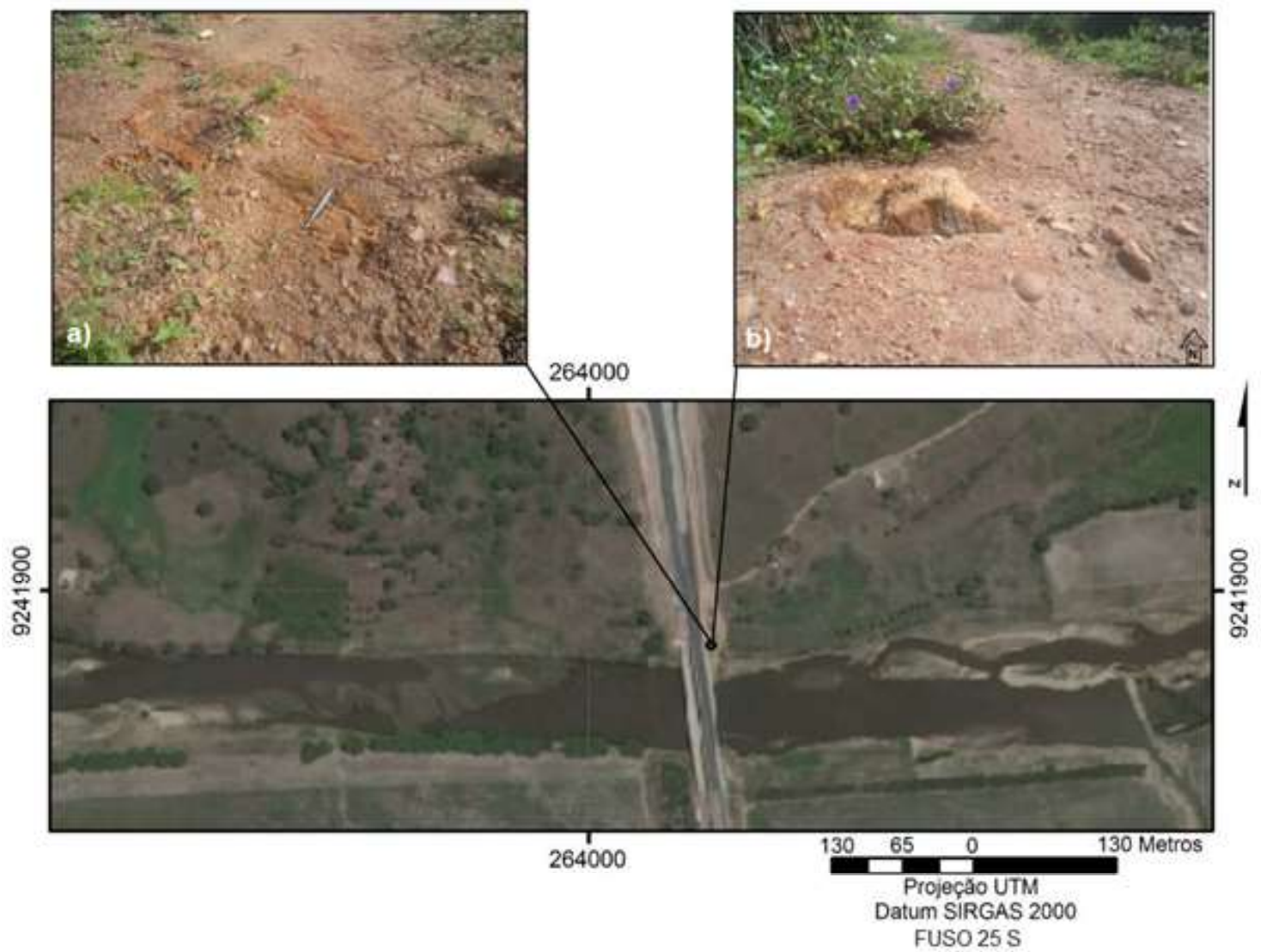

Figura 6-Afloramento granitico nas margens do rio Mamanguape. Observar afloramento de rochas graníticas intemperizadas na margem esquerda do rio Mamanguape (fotos a-b). Fonte: adaptado de Bing (2015). Fotos: Autores, 2015. 


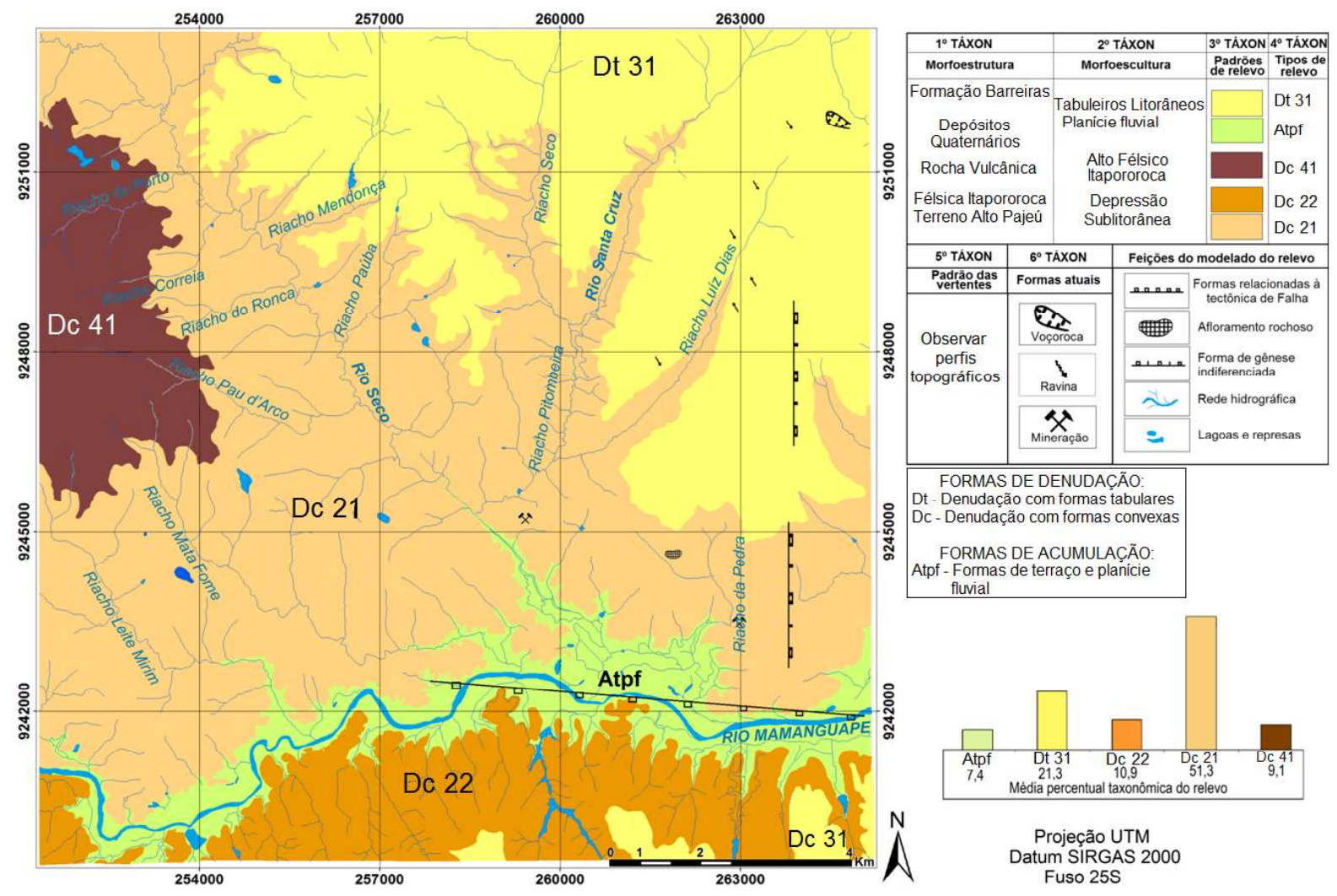

Figura 7 -Carta geomorfológica. Fonte: elaboração própria.

Na porção abrangida pelos sedimentos quaternários, são observados os amplos terraços e as planícies (Atpf) do rio Mamanguape e nas suas confluências com seus principais afluentes (Figura 8a). Essa é a única planície mapeável de toda a área, pois os demais cursos são de volume reduzido e/ou bastante confinados em seus vales.

A morfoescultura Dt 31, observada nos Tabuleiros Litorâneos, é configurada por formas de dissecação que originam vertentes côncavas com topos tabulares apresentando entalhamento dos vales com intensidade média $(40-80 \mathrm{~m})$ e dimensão interfluvial média classificada como muito grande $(>1500 \mathrm{~m})$ (Figura $8 b)$. Esse tipo de relevo está localizado amplamente por toda a porção nordeste, dentro dos limites dos municípios de Rio Tinto, Mamanguape, e em alguns pequenos trechos do extremosul/sudeste, próximo ao flanco direito do rio Mamanguape, contemplando uma pequena porção do município de Capim.

Na morfoestrutura dos Terrenos do Alto Pajeú, foi atribuída a subdivisão morfoescultural de Depressão Sublitorânea com os padrões de formas (Dc21 e Dc22) para os relevos com topos suavemente convexos (Figura 9). Nessa zona de entalhamento médio, o Dc21 abrange a porção central da carta, cuja drenagem principal é representada pelo rio Seco e seus tributários, que entalham os vales com um aprofundamento médio variando entre 20 e $40 \mathrm{~m}$, e uma dimensão interfluvial muito grande, maior que $1.500 \mathrm{~m}$.

Na porção que abrange o Dc22, localizado ao sul na folha Itapororoca, os rios se caracterizam por um nível de entalhamentos médio dos vales, variando entre 20 e $40 \mathrm{~m}$. Essas características de dissecação dão origem a formas colinosas (perfil 1). A dimensão interfluvial do vale do rio Mamanguape é grande (1.500 a 700m).

O relevo apresentado nesse trecho do perfil se destaca por apresentar as menores cotas altimétricas da área de estudo, não ultrapassando os $80 \mathrm{~m}$ em toda a extensão. A morfologia é densamente recortada por diversos canais de primeira e segunda ordem que estão encaixados em vales assimétricos, com vertentes retilíneas e convexas. Esses vales assimétricos separam linhas cumeadas, côncavas, com topos planos e basculados em alguns pontos. Ressalta-se que, apesar de os canais hidrográficos possuírem apenas parte de seus fluxos contemplados dentro da folha Itapororoca, é nítida a observação de que esse trecho se distingue dos canais da margem esquerda do rio Mamanguape pela maior densidade de canais de drenagem e pela pouca variação altimétrica com relação ao setor norte da folha Itapororoca, principalmente nos terrenos abrangidos pela Formação Barreiras. 
Souza A. S. \& Furrier M.

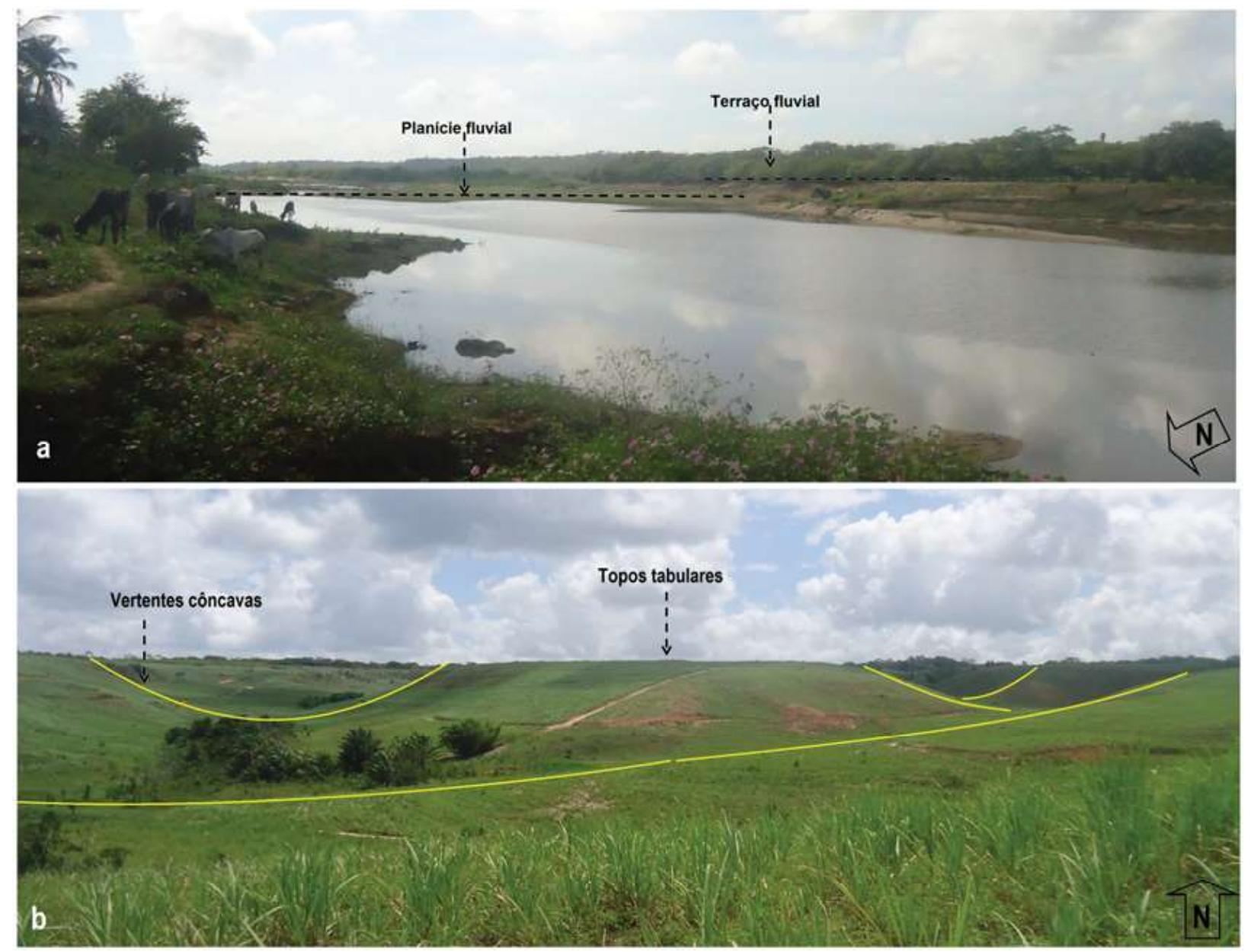

Figura 8 - a) planície e terraço fluvial do rio Mamanguape nas proximidades da BR 101; b) formas dissecadas nos Tabuleiros Litorâneos na cabeceira de drenagem do rio Santa Cruz, município de Mamanguape. Fonte: elaboração própria.

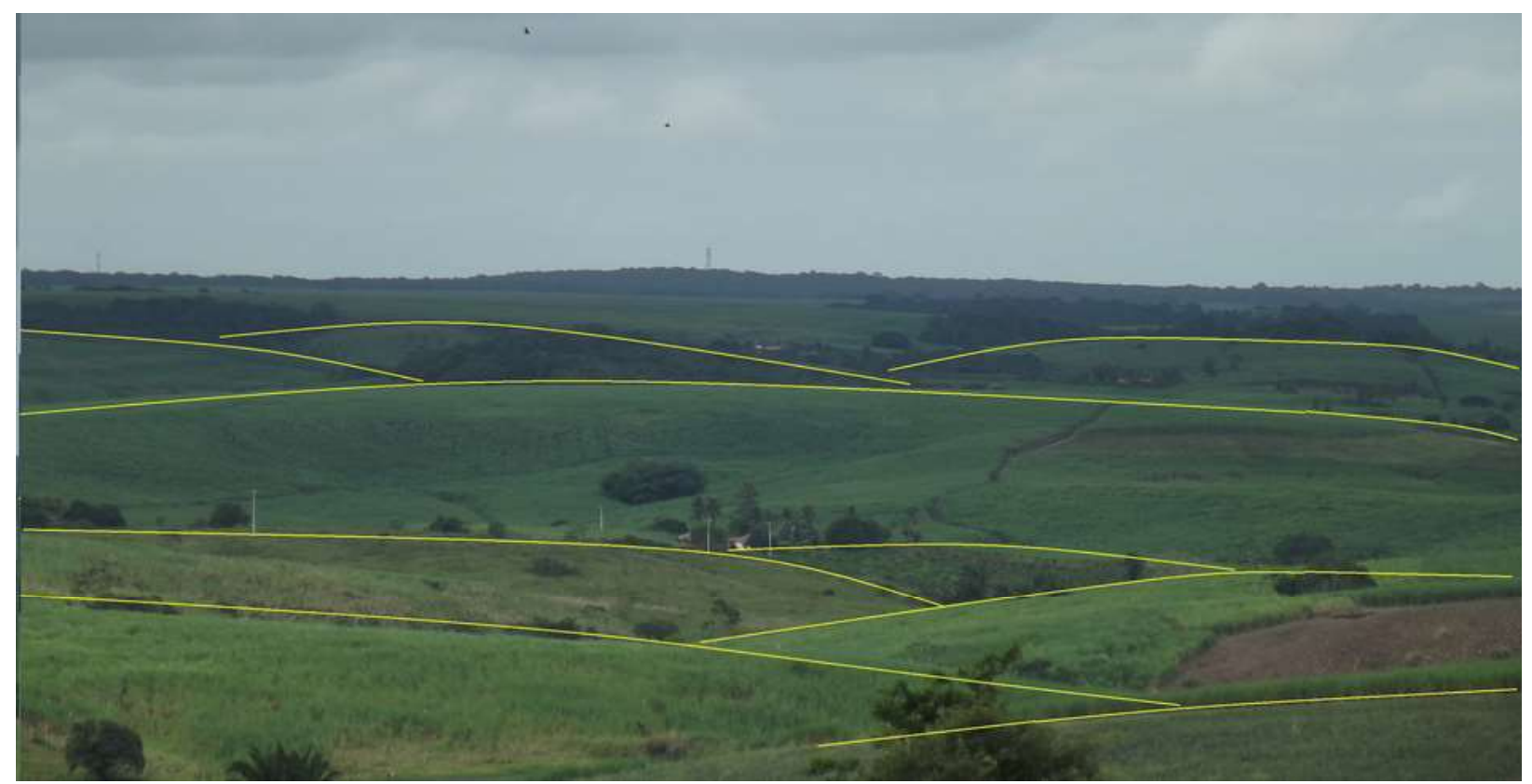

Figura 9 - Formas colinosas suavemente convexas (Dc21), utilizadas para o cultivo de cana-de-açúcar, no município de Itapororoca. Fonte: elaboração própria. 


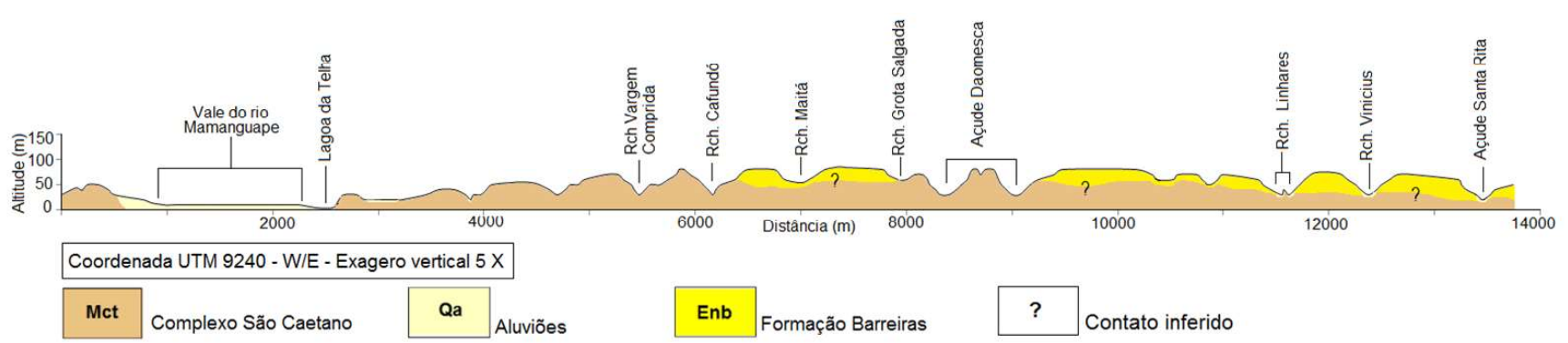

Figura 10 - Perfil 1. Fonte: elaboração própria.

A morfoestrutura Dc41 observada na Rocha Vulcânica Félsica Itapororoca comporta a morfoescultura definida como Alto Félsico Itapororoca. Esse padrão está situado na porção noroeste da folha Itapororoca, dentro dos limites do município de Itapororoca, onde o relevo é caracterizado por uma ampla área de elevação do substrato cristalino de idade cretácea.
Nesse trecho (vide perfil 2), o relevo realça parte do Alto Félsico Itapororoca, apresentando uma morfologia suavemente côncava no topo, com trechos relativamente planos, também apresentados por Silva (2014). A cota altimétrica do Alto Félsico Itapororoca ultrapassa os $170 \mathrm{~m}$, demonstrando nítido controle sobre toda a drenagem deste setor da área de estudo.

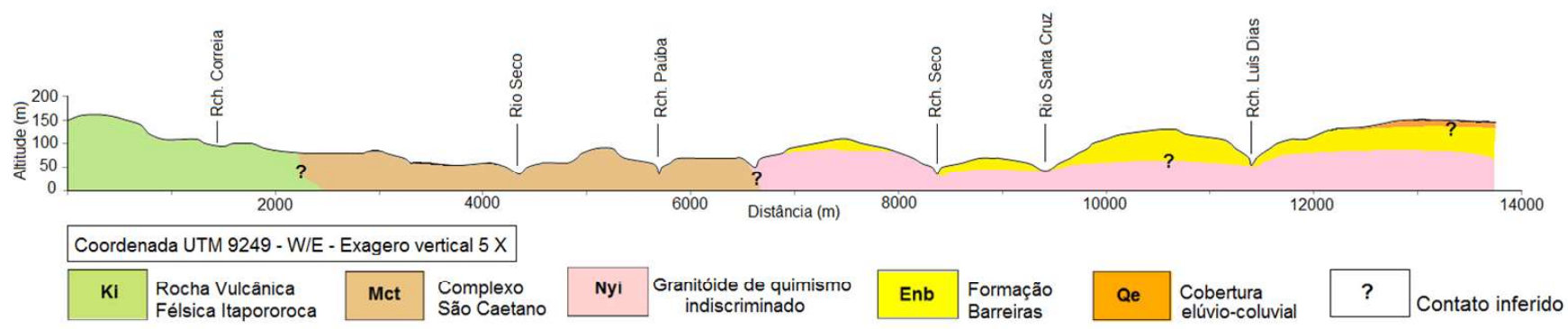

Figura 11 - Perfil 2. Fonte: elaboração própria.

Ainda no perfil 2, observa-se que algumas vertentes projetadas sobre substratos cristalinos apresentam desníveis escalonados. O vale do rio Seco possui vertentes côncavas, indicando soerguimento da área. O interflúvio esquerdo do rio Seco apresenta uma morfologia côncava, com vertentes suavemente convexas. Outra feição que se destaca nesse trecho de terrenos cristalinos é o entalhe em $\mathrm{V}$ com vertentes retilíneas do riacho Paúba. A sequência do perfil apresenta uma série de colinas assimétricas dissecadas pelos vales do riacho Seco, do rio Santa Cruz e do riacho Luís Dias, respectivamente, sobre o táxon Dt31.

Nos flancos da morfoestrutura do Alto Félsico Itapororoca, os vales dos riachos que dissecam a paisagem por meio de drenagem radial centrípeta exibem formas de topo convexo (Dc), o que sugere que os processos denudacionais atuaram e atuam de forma mais intensa nessa área. Essas feições de entalhe médio dos vales forte ( 80 a $160 \mathrm{~m})$ e dimensão interfluvial média muito grande $(>1.500 \mathrm{~m})$ sugerem que a incisão e a dissecação dos vales da morfoestrutura do Alto Félsico Itapororoca demonstram estar sob forte processo denudacional, pela sua elevada altimetria, que contribui para o aumento da energia de escoamento nas vertentes e a possibilidade de erosão por meio dos fluxos hídricos.

\subsection{Modelo Digital de Elevação (MDE)}

O MDE (Figura 12), elaborado a partir da folha Itapororoca, corrobora a constatação detalhada de inúmeras nuances morfológicas que configuram o relevo da área em questão. Entre as unidades morfológicas observadas, algumas estruturas merecem destaque, pela discrepância altimétrica e direção e padrão anômalos dos canais hidrográficos, corroborando a presença marcante de indícios associados a processos tectônicoestruturais ocorridos durante a morfogênese do relevo. 
Aárea compreendida pelo Alto Félsico Itapororoca, na porção noroeste, alcança altitude de $175 \mathrm{~m}$. Trata-se de uma estrutura oblonga de topo suavemente côncavo, cuja estrutura encontra-se parcialmente presente na carta Itapororoca, na qual é possível a observação da dissecação de suas vertentes por canais que estão atrelados ao controle morfoestrutural presente nessa unidade, dando origem a uma drenagem radial centrípeta, com presença de inúmeros canais retilíneos e inflexões agudas.

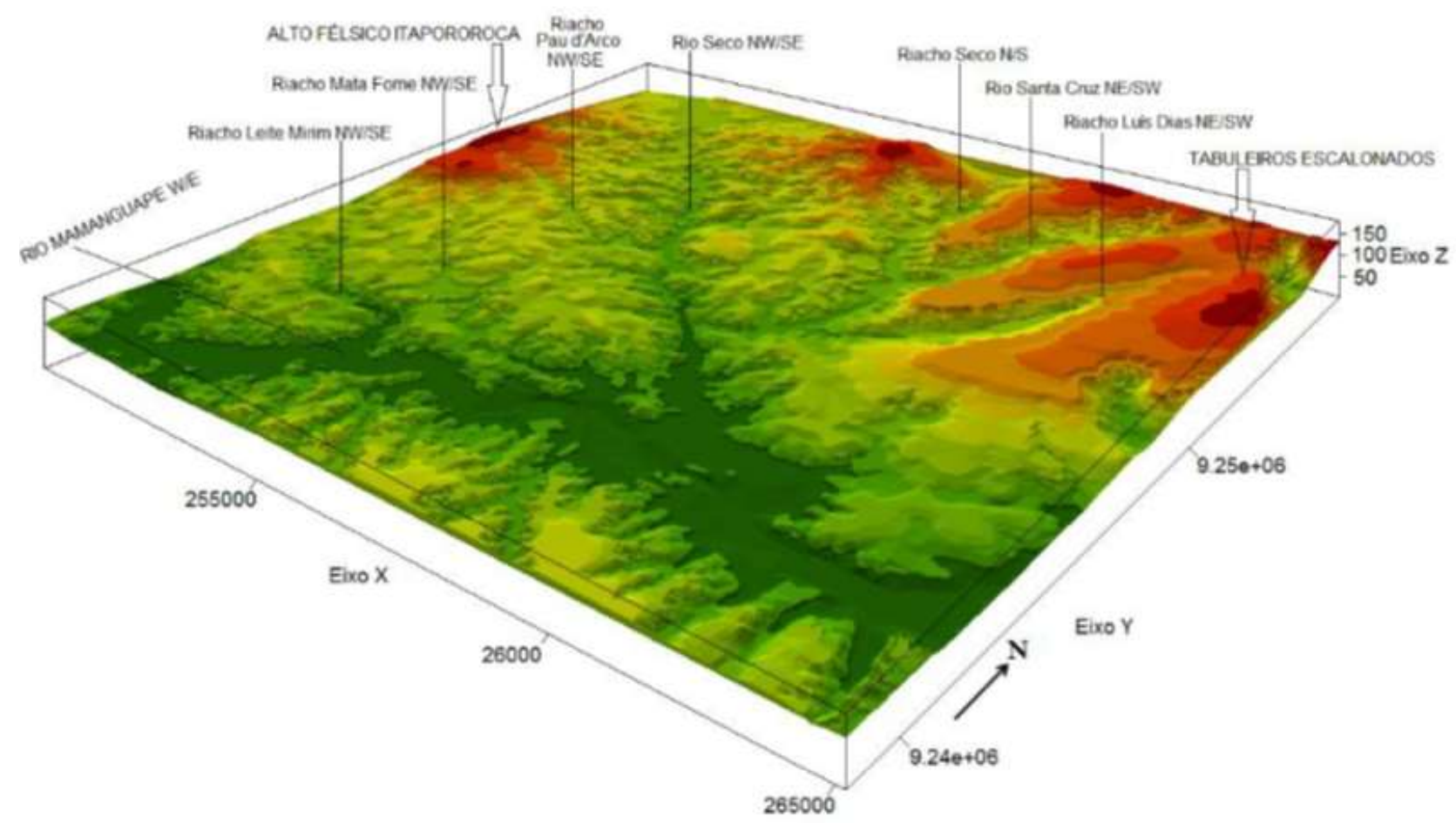

Figura 12 - Modelo Digital de Elevação (MDE). Fonte: elaboração própria.

A discrepância altimétrica da porção norte, em comparação com o sul da carta, bem como o padrão anômalo de alguns canais, remetem a duas possíveis causas genéticas: uma relacionada aos falhamentos e/ ou soerguimentos tectônicos pretéritos já estudos em trabalhos de cunho geológico citados neste artigo; e outra fortemente atrelada à composição litológica, constituída pela Rocha Vulcânica Félsica Itapororoca (Ki), com alta concentração de sílica, fato que pode resultar numa maior resistência dessa unidade geológica aos processos erosivos.

Nessa perspectiva, constata-se que tanto o Alto Félsico Itapororoca, estruturado na base litológica (Ki), como o trecho dos Tabuleiros Litorâneos condicionam fortemente a drenagem da área. Com relação aos cursos de água localizados sobre os Tabuleiros, os mesmos convergem para o rio Seco, a exemplo do riacho Luiz Dias de direção NE-SW. Nas vertentes desses riachos entalhados na Formação Barreiras foi observado inúmeras ravinas. Também foi verificado processo voçorocamento no setor nordeste da área, nas proximidades da BR 101. (Figura 13).

Com relação às feições anômalas observadas no relevo, identificadas na carta geomorfológica, destacaram-se: (a) estrutura dômica oblonga, resultante de erosão da intrusão que estrutura o Alto Félsico Itapororoca; (b) borda de patamar estrutural, que compõe o escalonamento dos Tabuleiros Litorâneos, compreendido por uma superfície tabular em forma de degrau (Figura 14); (c) forma relacionada à tectônica de falhamento, que estruturou o soerguimento da porção norte da área de estudo (porção da margem esquerda do rio Mamanguape) e a subsidência que confina o grabén do rio Mamanguape; e, por fim, (d) as inúmeras anomalias de drenagem presentes em diversos canais da área. 
Técnicas de Mapeamento Geomorfológico Aplicadas em Escala de Detalhe

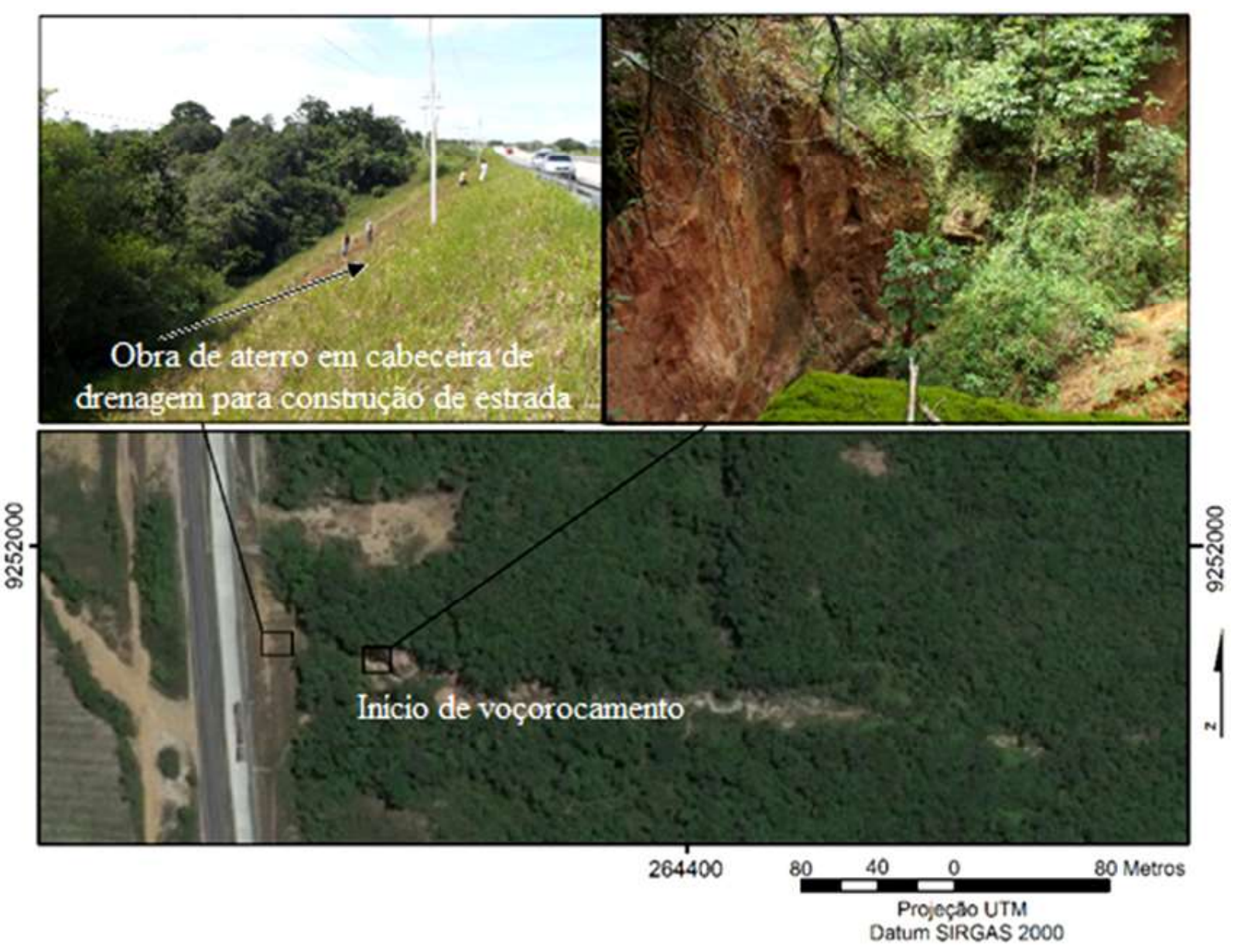

Figura 13 - Desenvolvimento de voçoroca no município de Rio Tinto, às margens da BR 101. Fonte: elaboração própria.

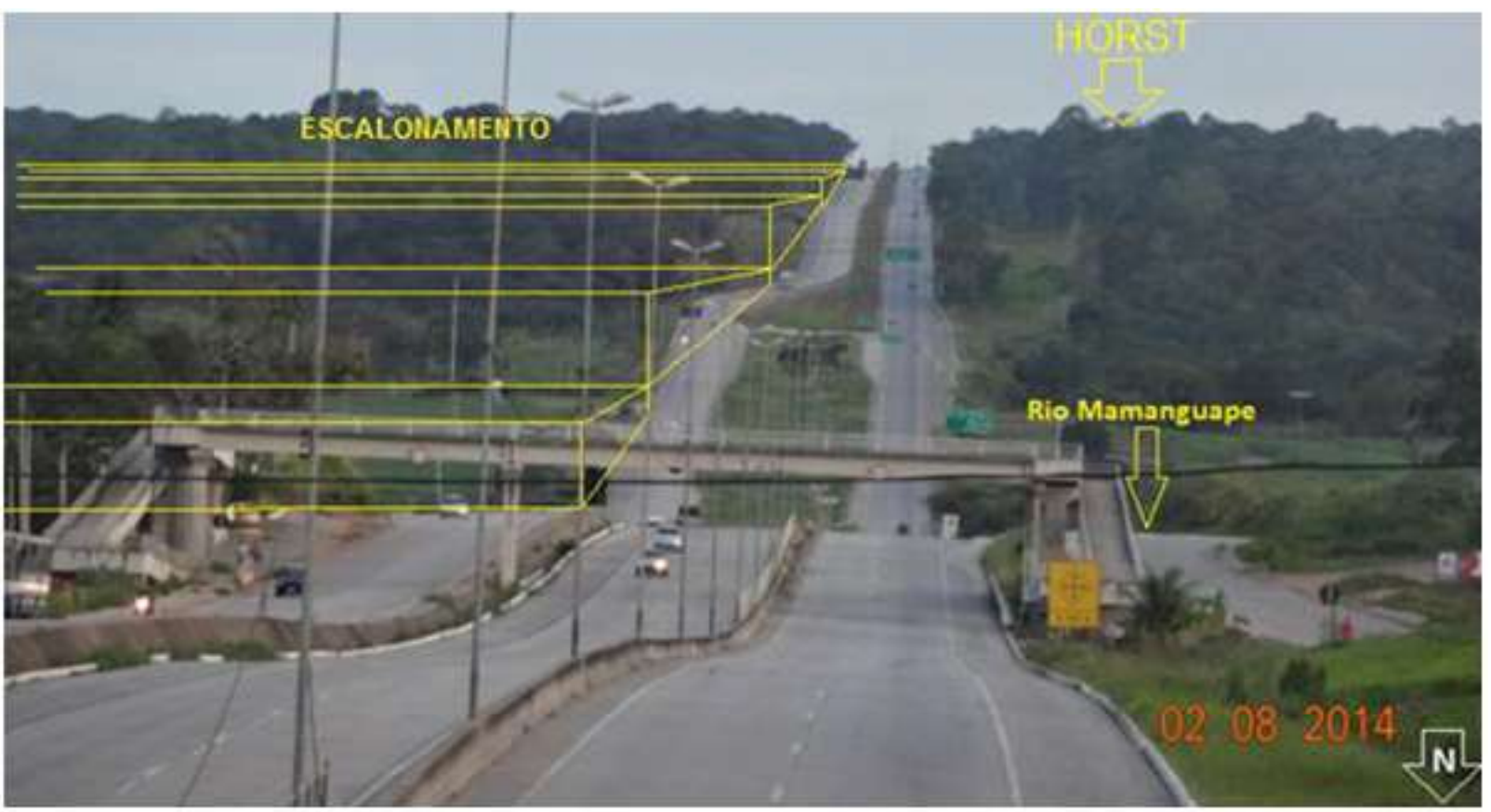

Figura 14 - Topografia escalonada da margem esquerda do rio Mamanguape. Fonte: elaboração própria. 


\section{Considerações Finais}

As técnicas aplicadas na elaboração dos produtos cartográficos do presente trabalho possibilitaram apresentar resultados que, combinados, trouxeram informações detalhadas acerca das perspectivas alçadas nos objetivos da análise, na qual foi possível detalhar com precisão algumas das características geomorfológicas e estruturais do relevo da área.

Trabalhos como estes permitem alcançar, com escala de detalhe, o entendimento das relações entre o relevo e o padrão litológico, realçando as feições resultantes da interface entre ambos, que, associados, dão origem à configuração atual do relevo. Dessa forma, é preciso ressaltar que quanto maior a escala empregada, maior será a possibilidade de observação e entendimento da morfologia e das peculiaridades morfométricas do terreno, permitindo, assim, propiciar meios pelos quais outros trabalhos sejam desenvolvidos no afã de apresentar informações que permitam o conhecimento pormenorizado do relevo por meio dos produtos cartográficos apresentados, de maneira que os processos naturais e antrópicos possam ser conhecidos e planejados visando o uso eficaz do terreno.

É importante destacar que em trabalhos de cunho geomorfológico e/ou de mapeamento geomorfológico a geologia deve ser destacada, em seu caráter estrutural, litológico e tectônico, haja vista que a o entendimento atual é de que o Brasil não é isento de ajustes tectônicoestruturais. Essa perspectiva foi enfaticamente abordada neste trabalho, pois para cada morfoestrutura se mapeou as morfoesculturas correspondentes, além de ser atribuídos aspectos morfométricos.

Cabe destacar, também, que a aplicação de outras técnicas e procedimentos, como a elaboração e análise de outras representações, por exemplo: perfis topográficos transversais, mapas hipsométricos, de declividade e pedológicos, aplicação de morfometria na rede hidrográfica, entre outros, pode ampliar substancialmente o entendimento dos processos e formas dominantes. Cabe salientar que o cerne deste trabalho foi o mapeamento geomorfológico com base geológica ajustada e não o detalhamento dos processos quaternários atuais. Contudo, a base fornecida neste trabalho poderá consubstanciar trabalhos geomorfológicos futuros direcionados à compreensão dos processos atuais.

Nessa perspectiva, a conjugação das técnicas com os produtos cartográficos gerados neste trabalho (carta geomorfológica, MDE e perfis topográficos) representam formas imprescindíveis de caracterização dos aspectos morfoestruturais e morfológicos, com possibilidade de aplicação em qualquer região que possua base cartográfica de escala grande com mapeamento geológico em escala compatível.

\section{Referências Bibliográficas}

ASMUS, H. E. Controle estrutural da deposição mesozoica nas bacias da margem continental brasileira. Revista Brasileira de Geociências, v. 5 n. 3, p. 160-175, 1975.

BARBOSA, G. V.; SILVA, T. C.; NATALI FILHO, T; DEL'ARCO, D. M.; COSTA, R. C. R. Evolução da metodologia para mapeamento geomorfológico do Projeto Radam Brasil. Boletim Técnico, Série Geomorfologia, n. 1, p. 187, 1984.

BEZERRA, F. H. R.; MELLO, C. L.; SUGUIO, K. A Formação Barreiras: recentes avanços e antigas questões. Geologia USP, Série Científica, v. 6, n. 2, p. III-VI, out. 2006.

BRASIL. Superintendência de Desenvolvimento do Nordeste. Divisão de Recursos Naturais. Serviço de Cartografia. Folha Itapororoca (SB.25-Y-A-V-4-NO), Recife: Sudene, 1974.

. Superintendência de Desenvolvimento do Nordeste. Biblioteca Celso Furtado. Catálogo das Cartas Topográficas do Nordeste do Brasil 1:25.000. Disponível em: $<$ http://www. sudene.gov.br/system/resources/BAhbBlsHOgZmSSJBMjAx Mi8wNS8wOS8xMV80OV81M185ODVfQ2FydGFfdG9wb2 dyYWZpY2FfZXNjYWxhXzFfMjUwMDAucGRmBjoGRVQ/ Carta topografica escala 1 25000.pdf $>$. Acesso em: 10 ago. 2013.

BRITO NEVES, B. B.; MANTOVANI, M. S. M.; MORAES, C. F.; SIGOLO, J. B. As anomalias geológicas e geofísicas localizadas ao norte de Itapororoca. Revista Brasileira de Geociências, v. 38, n. 1, mar. 2008.

BRITO NEVES, B. B.; RICCOMINI, C.; FERNANDES, T. M. G.; SANT'ANNA, L. G. O sistema tafrogênico terciário do saliente oriental nordestino na Paraíba: um legado proterozoico. Revista Brasileira de Geociências, v. 34 n. 1, p. 127-134, mar. 2004.

CHAVES, M. A. Modelos Digitais de Elevação hidrologicamente consistentes para a bacia Amazônica. 115 f. Tese (Doutorado em Ciência Florestal) - Universidade Federal de Viçosa, Viçosa, MG, 2002.

DIKAU, R. The application of a digital relief model to landform analysis. In: RAPER, J. F. (Ed.). Three dimensional applications in Geographical Information Systems. London: 
Taylor \& Francis, 1989. p. 51-77.

FURRIER, M. Caracterização geomorfológica e do meio físico da folha João Pessoa 1:100.000. 2007. 213f. Tese (Doutorado em Geografia). Programa de Pós-Graduação em Geografia Faculdade de Filosofia, Letras e Ciências Humanas (FFLCH), Universidade de São Paulo, São Paulo, 2007

FURRIER, M.; NÓBREGA, W. R.; SOUZA, A. S. Análise morfométrica e morfotectônica do gráben do rio Mamanguape e adjacências, borda oriental do estado da Paraíba, Brasil. Revista do Departamento de Geografia, USP, v. 28, p. 25-38, fev. 2014.

MAIA, R. P.; BEZERRA, F. H. R. Geomorfologia e neotectônica da bacia hidrográfica do rio Apodi-Mossoró - NE/Brasil. Mercator, v. 11, n. 24, p. 209-228, jan./abr. 2012.

MARQUES, J. M. Ciência Geomorfológica. In: GUERRA, A. J. T.; CUNHA, S. B. Geomorfologia: uma atualização de bases e conceitos. 7. ed. Rio de Janeiro: Bertrand Brasil, 2007. p. 23-45.

NUNES, B. A.; RIBEIRO, M. I. C.; ALMEIDA, V. J.; NATALI FILHO, T. Manual técnico de Geomorfologia. Rio de Janeiro: IBGE, 1994. (Manuais Técnicos em Geociências, n. 5).

PENCK, W. Morphological analysis of landforms. Londres: McMillan, 1953.

RODRIGUES, S. C.; OLIVEIRA, P. C. A. Cartografia do relevo: um estudo aplicado na região oeste de Minas Gerais. Revista
Brasileira de Geomorfologia, ano 8, n. 2, p. 37-44, 2007.

ROSS, J. L. S. O registro dos fatos geomórficos e a questão da taxonomia do relevo. Revista do Departamento de Geografia da FFLCH/USP, n. 6, p. 17-29, 1992.

SANTOS, E. J.; FERREIRA, C. A.; SILVA JÚNIOR, J. M. F. (Org.). Geologia e recursos minerais do estado da Paraíba. Recife: Ministério das Minas e Energia; CPRM, 2002.

SANTOS, E. J.; NUTMAN, A. P.; BRITO NEVES, B, B. Idades SHRIMP U-Pb do Complexo Sertânia: implicações sobre a evolução tectônica da zona transversal, Província Borborema. Geologia USP: Série Científica, v. 4, n. 1, p. 1-12, abr. 2004.

SILVA, I. C. Geomorfologia, hidrografia e tectônica da folha Araçaji 1:25.000, estado da Paraíba. 2014. 139 f. Dissertação (Mestrado em Geografia) - Universidade Federal da Paraíba, João Pessoa, 2014.

SILVEIRA, R. M. P.; SILVEIRA, C. T.; OKA-FIORI, C. Emprego de técnicas de inferência espacial para identificação de unidades de relevo apoiado em atributos topográficos e árvore de decisão. Revista Brasileira de Geomorfologia, v. 15, n. 1, p. 87-101, 2014.

SOUZA, J. O. P. Análise da precisão altimétrica dos Modelos Digitais de Elevação para área semiárida do Nordeste brasileiro. Revista do Departamento de Geografia, USP, v. 30, p. 56-64, dez. 2015. 